УДК 821.161. 2 "18/ 19"- 3.09 Л. Ян.

Л. М. Семененко

\title{
ЖІНОЧИЙ ДИСКУРС ПОВІСТІ ЛЮБОВІ ЯНОВСЬКОЇ «МІЙ РОМАН»
}

Семененко Л. М. Жіночий дискурс повісті Любові Яновської «Мій роман».

У статті розглядаються особливості художньої реалізації жіночого дискурсу в повісті «Мій роман» української авторки к. XIX - поч. XX століть Любові Олександрівни Яновської. Увагу зосереджено на специфічному поєднанні народницько-реалістичних та модерних рис у зображенні жіночої особистості. Наголошено на тому, що, звертаючись до традиційного наративу, письменниця 
вдається до новаторських підходів до створення жіночої постаті, здатної до активної діяльності, розвитку, переживання сильних почуттів. Презентація такого образу відбувається шляхом створення оригінальної психологічної парадигми.

Ключові слова: дискурс, жіночий образ, реалізм, модернізм, народництво, психологізм, парадигма.

Семененко Л. Н. Женский дискурс повести Любви Яновской «Мой роман».

В статье рассматриваются особенности художественной реализации женского дискурса в повести «Мой роман» украинского автора к. XIX - нач. XX веков Любови Александровны Яновской. Внимание акцентируется на специфическом сочетании народническо-реалистичных и современных черт в изображении женской личности. Указывается, что, обращаясь к традиционному нарративу, писательница прибегает к новаторским подходам к созданию женской фигуры, способной к активной деятельности, развитию, переживанию сильных чувств. Презентация такого образа происходит путём создания оригинальной психологической парадигмы.

Ключевые слова: дискурс, женский образ, реализм, модернизм, народничество, психологизм, парадигма.

Semenenko L. M. Female discourse in the story of L. Yanovska "My Romance".

This article investigates the literary realization features of female discourse in the story "My Romance" by Ukrainian author of XIX - early XX centuries Lyubov Yanovska. This paper focuses on a specific combination of populist and realistic modern features in characterizing of the female identity. Specific traits are revealed first of all in determining the dominant social sphere. Unlike traditional women farmers from Classical Literature or women of middle class in Modern Literature, the central character in the story "My Romance" is a female coming from an old aristocratic family. The author constantly emphasizes that the main character is financially ensured and socially protected lady till the certain period of time. Thus, at first glance, social problems relevant to classical literature are in some way eliminated. However, these problems in the text of chosen story become unexpectedly uncovered just in the female discourse. L. Yanovska pays much attention in her story to implementing the central female character as a mother. This traditional role is considered for a long time as not only the primary, but the only possible one. A woman mainly is a mother who cares not only about the financial status and future welfare of her children, but also she is concerned about their mental and spiritual state. In this aspect of the disclosure above mentioned author is very consistent, opening at first dynamics of psychological relationship between the mother and the children.

A woman-mother always takes care not only of her children's education, their health and welfare, but also about their morality, mood and feelings. This story reveals that the woman is trying to lead in educating her children quite new for that time ideas of expanding social relation spheres. Paying much attention to woman's maternal feelings the author consistently complicates her inner world, creating the psychological image. However, the most essential parts of a female discourse in the story "My romance" are associated with her love affairs, social work and psychological twists and turns experienced by the woman in love. Supplying the text with the scenes that clearly illustrate the variety of feelings and emotions associated with love, L. Yanovska presents its psychological sense quite 
sufficiently. Among new approaches used by the author one can mention depicting a female in the image of a person with integrity and strength that differs this story from the traditional female discourse texts. Referring to the traditional narrative, the writer manages to create innovative approaches in creating a female character, capable to be active, to develop and feel strong emotions. This image implementation is represented due to making an original psychological paradigm. paradigm.

Key words: discourse, female image, realism, modernism, populism, psychological

Проблеми жіночого буття завжди актуальні для української літератури. У період к. XIX - поч. XX століття, у добу раннього українського модернізму, жіночий дискурс набуває нового звучання, пов'язаного із суспільно-культурними змінами, перерозподілом гендерних ролей, активізацією феміністичного руху. Зміни торкнулися й літературного контексту, що виявилося, передусім, у зверненні до переосмислення жіночої постаті, уведенням у літературний обіг образу самодостатньої, сильної жінки, яка ставить перед собою завдання, відмінні від традиційних уявлень про роль і місце жінки в суспільному, життєвому укладі. Значна увага приділяється внутрішньому світу нової жіночої особистості. До новаторського зображення жінки в українській літературі цього часу звертаються перш за все визнані феміністки Наталія Кобринська та Ольга Кобилянська. Проте й у творчості інших авторів модерний дискурс жінки посідає значне місце.

Одним із таких авторів постає Любов Олександрівна Яновська, що не позиціонувала себе як феміністка, однак намагалася презентувати у своїй творчості нагальні проблеми українського буття межі XIX i XX століть, серед яких помітна роль належить жіночій проблематиці. На значущість зазначеного дискурсу для творчого доробку авторки вказували дослідники іï творчості (I. Приймак [1], Н. Шумило [2]), зазначаючи, що в іï творах своєрідно поєдналися традиційний та новаторський підходи до художнього осмислення проблем доби. Яскравим прикладом ставлення письменниці до жіночого питання $є$ повість «Мій роман», присвячена проблемі становлення жінки як особистості. 
Отже, мета статті полягає у з'ясуванні особливостей жіночого дискурсу повісті Любові Яновської «Мій роман».

Авторка звертається у творі до традиційного народницького наративу: оповідь ведеться від імені центрального персонажа, зберігаються ознаки класичного жанру повісті, наявні елементи чіткої композиційної структури. Однак відмінності виявляються вже у визначенні домінуючої соціальної сфери: на відміну від традиційної жінки-селянки (класична література) або жінки середнього класу (модерна література), центральним персонажем повісті «Мій роман» $є$ жінка аристократичного походження, давнього дворянського роду. Авторка неодноразово підкреслює, що Катерина Михайлівна матеріально забезпечена та соціально захищена до певного часу. У такий спосіб, на перший погляд, усувається актуальна для класичної літератури соціальна проблематика. У тексті твору вона набуває несподіваного висвітлення саме в жіночому дискурсі: родичі вказують Катерині Михайлівні на явну соціальну прірву між нею та вчителем іiі дітей, пізніше відмовляються 3 нею спілкуватися, жінка виявляється ізольованою від звичного кола. Зрештою, кузен Михайло (старший роду Кротецьких) намагається втручатися як в особисте життя жінки, так і в їі рішення щодо майбутнього дітей. Авторка наголошує, що на той період розвитку особистості Катерини Михайлівни категоричні претензії родичів не стають катастрофою, але примушують іï пережити гіркі хвилини розчарування. Традиційні аспекти жіночого дискурсу реалізуються в тому, що i родичі, i коханий сприймають тридцятип'ятирічну жінку 3 п'ятьма дітьми як цілком недосвідчену особу, яка не зможе дати ради ні собі, ні своїм дітям без допомоги чоловіка, наставника, керівника. У певних ситуаціях вони мають рацію: тривалий час Катерина Михайлівна серйозно не задумується над життям, спираючись на досвід оточення (яке таки щиро бажає добра їй i дітям). За задумом письменниці, жінка просто не має можливості долучитися до проблем буття. Своє життя до основних подій твору вона описує буквально кількома фразами: Я покинула батьківську оселю, 
переїхала в маєток свекра, $i$ з цьього часу почалося задля мене таке спокійне, тихе, рівне життя, щзо треба було мати гадюче серце, щуоби нарікати на свою долю. Чоловік любив, жалів мене, оберігав своє щзастя од недобрих очей, а мене од недобрих впливів; свекор та свекруха оточили мене найбільшим комфортом, великим числом наймитів, одібрали в мене всі клопоти, всі справи $і$ залишили одним один обов'язок тішити їхню старість унуками. І я бездоганно виконала цей обов'язок (3, с. 563). Однак спілкування 3 коханим, учителем народницького спрямування, робота в педагогічному товаристві, перипетії з родичами сприяють швидкому «дорослішанню» персонажа, розширенню світогляду, ускладненню характеру загалом.

У повісті значну увагу приділено розкриттю образу Катерини Михайлівни як жінки-матері. Ця традиційна роль довгий час сприймається нею як не лише основна, але і єдино можлива. Маючи п’ятьох дітей і ставши вдовою, жінка перш за все залишається матір'ю, яка дбає не лише про матеріальний стан та майбутній добробут своїх дітей, але й переймається їх душевним станом. У розкритті цього аспекту авторка є послідовною, репрезентуючи передусім динаміку психології стосунків матері й дітей. Дбаючи про долю старших, Марусі й Петруся, Катерина Михайлівна не лише відправляє дівчину до інституту, а хлопця «у корпус», але й турбується про те, як буде почуватися донька, коли мати буде виходити заміж, сама відчуває певний сором перед дочкою: Що сказала б вона зараз, якими б очима подивилася на мене, коли б побачила мене в обіймах чужого мужчини? Коли б побачила, щуо я сплямила пам'ять ї̈ батька? Чи не підняла б вона мене на сміх? Чи не кинула б мені слова тяжкого докору? (3, с. 565). Купуючи хутір біля свого маєтку, мати робить це не тільки заради благополуччя Марусі, якій призначає цей хутір, але й уявляє, як буде почуватися донька в цьому дуже гарному місці, коли знайде собі «справжню пару». Жінка постійно опікується вихованням своїх меншеньких, турбується не тільки про їх здоров'я, добробут та навчання, але й про моральність, настрій, почуття. Більше того, Катерина Михайлівна намагається використовувати у 
вихованні цілком нові на той час ідеї розширення соціальної сфери спілкування: В моїй програмі виховання дітей стояло egalite, fraternite; синок швейщара був бажаним гостем у моїх синів, дві дочки кухаря щзонеділі приходили гратися до Ані (3, с. 585). Жінка дбає і про розваги для своїх дітей. Зворушливими у творі є сцени «гуляння на санках», свята біля ялинки та інші. Саме турбота про сина Миколку, що «став раптом безсовісним брехуном» $(3$, с. 567), змусила Катерину Михайлівну шукати для сина справжнього «путящого наставника», якого потім вона покохала. Приділяючи значну увагу материнським почуттям жінки, Любов Яновська послідовно ускладнює іiі внутрішній світ, поглиблює психологічний малюнок. У якийсь момент свого життя, приїхавши до маєтку, де зростали іiі діти, Катерина Михайлівна усвідомлює, що материнські турботи - це важлива, дорога, але тільки одна частина людського життя: Тут побачила я всі свої діти. Тут вони росли, навчалися ходити, бігати, балакати. Тут літали барвисті мрії дитячих голівок; ховалися по кутках страшні «хо» та всякі жахи; тут бродили тіні мого відчаю, щуо я переживала під час хвороби дітей. Потертий дитячими ніжками поміст; купка поламаних дитячих цяяьок у куточку за грубкою; ляльки на ослінчику в пишному, пошитому моӥми руками убранні; граматки, казки, пошматовані ілюстрачії - все задля дорогих спогадів матері. Але ж тільки самої матері! Задля мене ж самої, як цілої людини, так само, як і по всіх інших хатах - нічого! (3, с. 629). Увага читача привертається до модерного осмислення жіночого образу як людської особистості, яка повинна цілісно реалізуватися в житті.

Проте найбільш суттєвими частинами жіночого дискурсу повісті «Мій роман» стають історія кохання Катерини Михайлівни до вчителя Сави Григоровича, пов'язана 3 нею громадська робота та психологічні перипетії, пережиті жінкою через своє кохання.

Любов Яновська наділила Катерину Михайлівну скептичним ставленням до почуття любові, певною зневагою до романтичних стосунків: Щодо романів?.. Я позіхала, коли мені переказували романтичну сплітку. Я не могла присилувати себе, щзоб дочитати до 
кіния роман, про який кричали, писали, який давав протягом иілих місячів теми задля всяких рефератів та дебат. Я просто не розуміла романтичних драм, не могла повірити, щз можна таку самісіньку людину, як і я, грішна, поставити на п'єдестал, здіймати до неї, як до Бога, руки, офірувати їй своє життя, навіть честь. Мені здавалися просто божевільними як герої та героїні романів, так і їх автори та читачі (3, с. 566-567). I, відверто іронізуючи над власним «романом», жінка зізнається далі, «щуо початок роману забрала тільки одна хвилина. Одна-однісінька хвилина! Не довща за изю хвилину, щзо відділяе життя від смерті» (3, с. 567). Зауважимо: надалі, переживаючи хвилини власного кохання, Катерина Михайлівна буде захоплюватися цими ж романами, підкреслюючи в них «іноді цүілі сторінки». Зі щирим пафосом закоханої жінки оповідачка упевнено констатує: Мені здавалося, щуо жодна з героӥнь прочитаних мною романів усе ж таки не кохала так глибоко, так палко, як я (3, с. 601).

Удаючись до опису зародження почуття кохання, Любов Яновська пов'язує його із тим, що в іiї героїні відбувається «єднання 3 другою людською істотою!» (3, с. 576). Авторка детально фіксує перебіг психологічних станів Катерини Михайлівни, акцентуючи на тому, що жінка вперше відчула себе особистістю: $У$ изей вечір я знайшла себе. Вперше моє «я» з 'явилося як щось реальне, самостійне, з власною волею, власними симпатіями, означеними бажаннями. < ..> Тепер з одноманітної людської гущі виділилася людина одна, -може, найбільше не гідна з погляду цілого світу, але через віщось найбільше близька, а через те і найдорожча мойому «я». I всі обставини, $і$ всі умовини життя однині набували вартості в залежності від того, наскільки вони не перейшли волі та смаку того «я» (3, с. 576). Таке відкриття сталося завдяки вчителю, наставнику іï синів.

Обранець жінки не відзначається вродою і взагалі зовнішньою привабливістю: звичайні риси обличчя, опущені плечі, нерівна борідка, широкі пальці. На незграбній зовнішності та простому невибагливому одязі Сави Григоровича не раз акцентується увага письменниці. Проте ті 
риси, які він виявляє у спілкуванні 3 дітьми і самою Катериною Михайлівною, створюють у неї враження «розумного, сердечного наставника, приятеля дітей» (3, с. 568). Дійсно, система виховання, яку втілює Сава Григорович, призводить до того, що «хлопці повеселішали, помоторнішали, набрали тіла та крові при новому режимі» (3, с. 569). Він упевнено захищає Миколку, переконуючи матір, що це найкраща дитина з розвинутою фантазією. Він терпляче пояснює Ані механізм годинника, коли дівчинка виявляє зацікавленість. Він охоче ставить ялинку й організовує новорічне свято для цілої родини, при цьому його ялинка більше подобається дітям, ніж мамина. Він готовий їхати 3 дітьми на конях із санками, щоб підтримати їх гарний настрій. У розповіді про своє життя Сава Григорович повідомляє перш за все про свою діяльність як педагога. Зрештою, його намагання залучити Катерину Михайлівну до громадської діяльності та сама ця діяльність послідовно відповідають ідейним концепціям народництва. Однак для жінки, яка тільки починає усвідомлювати себе як особистість, слова про те, що «вона виконала тільки один обов'язок здорової, нормальної женщини» і не виявила «інших сил та здібностей» (3, с. 576), стають потужним поштовхом не лише для зародження почуття кохання, але й для громадської діяльності, у яку вона активно залучається. Під впливом коханого Катерина Михайлівна робить переклади книжок, редагує переклади, зроблені іншими, виступає на людях, віддає та збирає гроші на «дійсно потрібну і корисну справу». Вона навіть намагається агітувати жінок свого середовища. Заради кохання вона передає товариству бібліотеку, яку тривалий час збирали родичі іiі чоловіка, i це єдине, за чим потім пожалкує. Об'єктивно у творі Сава Григорович виявляє прихильне, дружнє ставлення до Катерини Михайлівни, він відповідально виховує іiі синів, тісно спілкується $з$ нею, залучає іiі до своєї діяльності, працює, цікаво проводить час. Він бачить у цій жінці передусім особистість, але жодного разу не говорить їй про своє кохання.

Уводячи в текст сцени, які виразно ілюструють різноманітні почуття й емоції, пов'язані з коханням, Любов Яновська презентує його 
психологію з достатньою повнотою. Катерина Михайлівна переживає в різний час і на різних етапах кохання зацікавленість, захоплення, надію, відчай, ревнощі, сором, тугу, радість, задоволення від життя, прагне дізнатися якомога більше про обранця свого серця. Показовим для закоханої є іï суб'єктивне сприйняття жінки, яку вважає своєю суперницею: Коротконога, угодована, з розпущеним бюстом, оголеною $i$ спереду, $і$ ззаду шиєю, в темно-блакитній, з широкими чорними розводами сукні, з обвислими щзоками, великими, круглими, виряченими сірими баньками (3, с. 640). При цьому сама Катерина Михайлівна характеризується як «одна з признаних красунь», яка «мала вигляд молодої жінки» (3, с. 616). У якийсь момент виявляється, що вона здатна на імпульсивні вчинки, не властиві ій раніше. Важливим для психологічної складової жіночого дискурсу твору є використаний авторкою прийом сновидіння, який набуває виразно символічного значення: Він сіпнув головою з усієї сили, щоби повернутися до тієї жінки, й невідомим способом здерлася вся шкірка з мого обличчя. Я почула нестерпимий біль. 3 обличчя полилася кров. Я затулила його рукою, - кров лилася через пальці. Я приклала хустку, - вона відразу просякла кров'ю. Я кинулася шукати чого-небудь, щзоби затулити рану, й бігала по кімнаті, - кров потоками заливала мої сліди (3, с. 596).

Новим, відмінним від традиційного жіночого дискурсу бачиться й те, що жіноча особистість набуває цілісності й сили, яких не сподівалася від себе. Після того, як жінка побачила свого обранця у відвертому флірті 3 іншою, саме набута цілісність дала їй здатність усвідомити значущість того, що відбулося в ії житті: Чого ти, власне, так збентежилося, бідолашне серце? Що саме так болюче вразило тебе: чи пересвідчення, щзо Сава Григорович не камінь, не дерево, не аскет, чи переконання, щуо він не кохає тебе? Але ж тебе кохав $i$ чоловік-небіжчик, і Олексій, та чи зогріли вони свойм коханням твоє серце, чи дали хоч хвилину щзастя $і$ чи не пішла б ти на той світ, так $i$ не зазнавши ні солодких мук, ні зрадливих радощів кохання, коли б не покохала сама? (3, с. 641). 
Отже, жіночий дискурс повісті «Мій роман» Любові Яновської відзначається своєрідним синкретизмом традиційного та новаторського підходів до зображення жіночої особистості. Авторка загалом не змінює традиційних гендерних ролей, однак, значну увагу приділяє жіночій особистості як такій, що здатна до сильних почуттів, активної діяльності та розвитку. Виразний психологізм художньої реалізації жіночого образу дає змогу говорити про створення унікальної психологічної парадигми, актуальної як для доби межі XIX та XX століть, так і для сьогодення.

\section{Література}

1. Приймак I. В. «Мій роман» Л. Яновської : гендерні аспекти твору / I. В. Приймак // Актуальні проблеми філології і перекладознавства : зб. наук. пр. Вип. 3. - Хмельницький, 2007. - С. 142-144.

2. Шумило Н. М. Подолати в душі зло... / Н. М. Шумило // Яновська Л. О. Твори : у 2-х т. - Т. 1. : Оповідання, повісті. - К. : Дніпро, 1991. - С. 5-28.

3. Яновська Л. О. Мій роман / Л. О. Яновська // Яновська Л. О. Твори : у 2-х т. Т. 1. : Оповідання, повісті [упорядн. та авт. передм., приміт. : Н. М. Шумило]. - К. : Дніпро, 1991. - 718 c.

Стаття надійшла до редакиії 23.11.2016 р. 